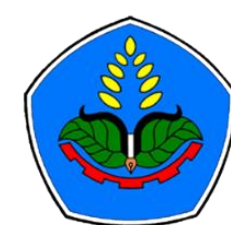

AGROPROSS

National Conference

Proceedings:

Peningkatan Produktivitas Pertanian Era Society 5.0 Pasca Pandemi

Tempat : Politeknik Negeri Jember

Tanggal : 22 Juli 2021

Publisher :

Agropross, National Conference Proceedings of Agriculture

ISBN : 978-623-94036-6-9

DOI : 10.25047 /agropross.2021.231

\title{
Pengaruh Pemberian Plant Growth-Promoting Bacteria Indigenous terhadap Pertumbuhan Tanaman Bawang Merah (Allium ascalonicum)
}

\author{
Author(s): Gallyndra Fatkhu Dinata ${ }^{(1)^{*}}$, Luqman Qurata Aini( ${ }^{(1)}$, Abdul Latief Abadi $^{(1)}$ \\ (1) Jurusan Hama dan Penyakit Tanaman, Fakultas Pertanian, Universitas Brawijaya \\ * Corresponding author: gallyndra@gmail.com
}

\begin{abstract}
Research on Plant Growth-Promoting Bacteria (PGPB) was developed to implement a sustainable farming system. The results of the exploration of indigenous PGPB in nature such as coffee litter add information on biological control. The aim of this study was to determine the indigenous PGPB isolated from coffee litter in UB Forest had an effect on the growth of shallot plants. This research was conducted in February - April 2020 in Malang using a Randomized Block Design (RBD) with six treatments and three replications. The study used seed treatment on healthy shallot bulbs of the Philip variety without pathogen inoculation treatment. The treatments including control and five indigenous PGPB isolates Alcaligenes faecalis, Bacillus mycoides, Clostridium sp., Erwinia sp., and Pseudomonas sp. The results showed that the application of indigenous $P G P B$ had a significant effect on the growth of shallot plant height. However, the increase in growth variables was not followed by an increase in the number of leaves and resistance compounds such as peroxide enzymes produced in shallots. This study is a preliminary research to determine the PGPB isolates which were tested for their ability to increase the growth of shallot plants when induced by fusarium wilt disease.
\end{abstract}

Keywords:

Biological control;

Indigenous

bacteria;

$P G P B$;

Shallot

\section{Kata Kunci: ABSTRAK}

indigenous;

Penelitian Plant Growth-Promoting Bacteria (PGPB) banyak dikembangkan untuk

Bawang merah; menerapkan sistem pertanian yang berkelanjutan. Hasil dari eksplorasi

Pengendalian hayati; PGPBindigenousdi alam seperti UB Forest menambah informasi pengendalian hayati yang ramah lingkungan. Tujuan dari penelitian ini adalah untuk mengetahui isolatPGPB indigenous yang diisolasi dari serasah kopi UB Forest memiliki pengaruh terhadap pertumbuhan tanaman bawang merah. Penelitian ini dilakukan pada Februari - April

PGPB 2020 di KabupatenMalang menggunakan Rancangan Acak Kelompok (RAK) enam perlakuan dan tiga ulangan. Penelitian menggunakan seed treatment pada bibit bawang merah sehat varietas Philip tanpa perlakuan inokulasi patogen. Perlakuan yang digunakan antara lain kontrol dan lima isolat PGPB indigenous yaitu Alcaligenes faecalis, Bacillus mycoides, Clostridium sp., Erwinia sp., dan Pseudomonas sp.Hasil penelitian menunjukkan bahwa pemberian PGPB indigenous memberikan pengaruh yang nyata pada pertumbuhan tinggi tanaman bawang merah. Namun, peningkatan parameter pertumbuhan tersebut tidak diikuti oleh peningkatan jumlah daun dan produksi senyawa ketahanan yaitu enzim peroksida yang dihasilkan pada daun bawang merah. Penelitian ini merupakan penelitian awal untuk menentukan isolat PGPB indigenous yang selanjutnya akan diuji kemampuannya dalam meningkatkan pertumbuhan tanaman bawang merah apabila dilakukan induksi penyakit layu fusarium. 


\section{PENDAHULUAN}

Bawang merah merupakan komoditas hortikultura yang banyak diminati oleh masyarakat Indonesia. Bawang merah banyak digunakan sebagai rempah bumbu penyedap makanan dan bahan obat tradisional. Kegunaan yang beragam menyebabkan tanaman bawang merah mempunyai peluang usaha yang baik dalam pemasarannya. Kebutuhan masyarakat pada bawang merah terus meningkat seiring pertambahan jumlah penduduk dan daya beli.Namun, serangan organisme pengganggu tanamanmasih menjadi kendala besar bagi produksi bawang merah yang sering dihadapi pada proses budidaya salah satunya penyakit layu fusarium.

Pengendalian hayati merupakan teknik pengendalian melalui pendekatan ramah lingkungan yang mulai banyak dikaji dan diterapkan pada pertanian di dunia. Salah satu pengendalianpada proses budidaya yang dapat dilakukan untuk mengendalikan penyakit pada bawang merah adalah menerapkan pengendalian hayatidengan memanfaatkan mikroorganisme bermanfaat seperti Plant Growth-Promoting Bacteria (PGPB). Penggunaan mikroorganisme bermanfaat dapat mengurangi pemakaian pestisida kimia sehingga dapat mengurangi pencemaran di lingkungan pertanian. PGPB mengkolonisasi akar tanaman sehingga memberikan efek yang menguntungkan terhadap tanaman. Pada beberapa penelitian bakteri pemacu pertumbuhan dapatmenghasilkan pertumbuhan tanaman yang lebih cepat. Pemberian aplikasi lima isolat bakteri pemicu pertumbuhan tanaman yaitu PGPR sama baiknya dengan aplikasi Trichoderma dalam meningkatkan pertumbuhan tanaman bawang merah pada parameter luas permukaan daun dan bobot kering total dibandingkan kontrol (Hafri et al., 2020). PGPR juga memberikan hasil pertumbuhan yang signifikan terhadap tinggi tanaman maksimum, jumlah cabang maksimum, jumlah daun maksimum, bobot basah, dan bobot kering polong(Khalimi \& Wirya, 2009).

Penelitian ini merupakan penelitian lanjutan yang telah dilakukan dan masih dalam tahap pengembangan. Peneliti sebelumnya menemukan potensi PGPBindigenous atau bakteri pemicu pertumbuhan asli dari serasah kopi di UB Forest yang berperan sebagai agens pengendali hayati pada penyakit layu fusarium baik secara in vitro maupun in vivo (Dinata et al., 2021). Tujuan dari penelitian ini adalah melihat potensi PGPB indigenous tersebut dalam meningkatkan pertumbuhan tanaman bawang merah tanpa diinduksi oleh patogen penyebab penyakit tanaman.

\section{BAHAN DAN METODE}

Penelitian dilaksanakan pada bulan Februari - April 2020 menggunakan screen house, di Desa Kebonagung, Kabupaten Malang. Bahan yang digunakan yaitu, bibit bawang merah sehat varietas Philip asal Batu, isolat PGPB Indigenous UB Forest yang sudah diuji kemampuannya dan bukan merupakan patogen tanaman (Dinata, 2018), tanah, kompos, dan polybag. Inokulasi PGPB pada bawang merah dimulai dari persiapan bibit dan media tanam. Bibit bawang merah sebelumnya dibersihkan dengan $\mathrm{NaOCl1 \%}$ dan memotong sepertiga bagian bawang merah. Bibit bawang merah yang digunakan merupakan varietas Philip berasal dari Kota Batu. Aplikasi pemberian bakteri mengacu pada metode seed treatment (Isniah and Widodo, 2015), umbi bawang merah diletakkan pada wadah yang berisi suspensi bakteri antagonis dengan bagian bawah umbi mengenai suspensi bakteri dengan kerapatan $10^{9} \mathrm{CFU} / \mathrm{ml}$ dan dibiarkan selama 30 menit kemudian dikering-anginkan.Media tanam steril dilakukan dengan menyiapkan tanah dan kompos dengan perbandingan 1:1 (v:v) 
disiram menggunakan formalin $4 \%$ secara merata, ditutup selama 7 hari dengan plastik kemudian dibukaselama 7 hari. Tanam umbi bawang merah pada polybag yang telah diisi media tanam.

Rancangan percobaan yang digunakan adalah Rancangan Acak Kelompok (RAK) dengan enam perlakuan dan tiga ulangan. Variabel yang diamati adalah data pertumbuhan tanaman dan senyawa pertahanan yang dihasilkan. Data pertumbuhan meliputi tinggi tanaman dan jumlah daun tanaman bawang merah. Pada data senyawa pertahanan yaitu enzim peroksidase dari daun bawang merahmenggunakan metode Bateman (Resti et al., 2016). Analisadata secara kuantitatif dengan menggunakan ANOVA dan dilakukan uji lanjut dengan menggunakan uji Duncan.

\section{HASIL DAN PEMBAHASAN}

Hasil pertumbuhan tanaman bawang merah yang diberi perlakuan PGPB indigenous memberikan hasil yang nyata terhadap tinggi tanaman bawang merah (Tabel 1).Hasil penelitian menunjukkan adanya peningkatan tinggi tanaman pada 15 dan 20 hari setelah tanam. Pada 15 hari setelah tanam rerata tinggi tanaman bawang merah adalah 25,39-29,44 cm meningkat menjadi $29,77-33,17 \mathrm{~cm}$. Pada 15 hari setelah tanam, perlakuan Clostridium sp. menghasilkan nilai tinggi tanaman palingbesar senilai 29,44 cm namun tidak lebih baik dari semua perlakuan isolat PGPB. Pada 20 hari setelah tanam,Pseudomonas sp.memberikan nilai tinggi tanaman paling besar senilai 33,17, namun tidak lebih baik dari ketiga isolat PGPB lainnya dan kontrol. Pada sejumlah penelitian Clostridium sp. merupakan salah satu bakteri bermanfaat yang banyak digunakan sebagai pemacu pertumbuhan tanaman(Gamalero \& Glick, 2011). Clostridium sp. diduga mengeluarkan senyawa yang bermanfaat pada tanaman bawang merah, sehingga dapat memacu pertumbuhan tanaman melalui pertumbuhan tinggi tanaman. Clostridium sp. mampu meningkatkan pertumbuhan tanaman dengan memproduksi senyawa Giberelin yang dapat memacu pertumbuhan tanaman (Tsavkelova, et al., 2006).

Tabel 1. Rerata tinggi tanaman bawang merah yang diberi PGPB Indigenous

\begin{tabular}{lcc}
\hline \multirow{2}{*}{ Perlakuan } & \multicolumn{2}{c}{ Tinggi tanaman } \\
\cline { 2 - 3 } & $\mathbf{1 5}$ hst & $\mathbf{2 0 ~ h s t}$ \\
\hline Kontrol & $25,39 \mathrm{a}$ & $30,86 \mathrm{ab}$ \\
A. faecalis & $26,33 \mathrm{ab}$ & $31,08 \mathrm{ab}$ \\
B. mycoides & $26,22 \mathrm{ab}$ & $29,77 \mathrm{a}$ \\
Clostridium $\mathrm{sp}$. & $29,44 \mathrm{~b}$ & $31,93 \mathrm{ab}$ \\
Erwinia sp. & $26,55 \mathrm{ab}$ & $31,31 \mathrm{ab}$ \\
Pseudomonas sp. & $27,68 \mathrm{ab}$ & $33,17 \mathrm{~b}$ \\
\hline
\end{tabular}

Keterangan:Bilangan yang disertai huruf yang sama pada kolom yang sama menunjukkan tidak berbeda nyata berdasarkan uji Duncan pada taraf kesalahan 5\%, hsi: hari setelah inokulasi. Data tinggi tanaman sebelum dianalisis dilakukan transformasi dengan akar kuadrat.Hst: hari setelah tanam.

Tabel 2. Rerata jumlah daun bawang merah yang diberi PGPB indigenous

\begin{tabular}{lcc}
\hline \multirow{2}{*}{ Perlakuan } & \multicolumn{2}{c}{ Jumlah daun } \\
\cline { 2 - 3 } & $\mathbf{1 5}$ hst & $\mathbf{2 0}$ hst \\
\hline Kontrol & 15,00 & 18,00 \\
A. faecalis & 14,65 & 15,27 \\
B. mycoides & 14,87 & 15,87 \\
Clostridium sp. & 16,42 & 14,67 \\
Erwinia sp. & 17,13 & 17,73 \\
Pseudomonas sp. & 16,13 & 20,87 \\
\hline
\end{tabular}

Keterangan: hst: hari setelah tanam

Hasil penelitian menunjukkan adanya peningkatan jumlah daun pada 15 dan 20 hari setelah tanam. Pada 15 hari setelah tanam rerata jumlah daun tanaman bawang merah adalah 15 - 17 helai daun meningkat 
menjadi 21 helai pada 20 hari setelah tanam. Pada hasil analisis ragam, parameter jumlah daun menghasilkan data yang tidak berbeda nyata pada kedua pengamatan (Tabel 2). Nilai rerata jumlah daun tanaman bawang merah menunjukkan bahwa pemberian PGPB tidak memberikan pengaruh yang berbeda terhadap jumlah daun tanaman bawang merah. Hasil penelitian Patading and Ai (2021) tentang penelitian serupa menyatakan bahwa penyiraman PGPR membuat jumlah daun meningkat namun tidak memberikan pengaruh yang nyata pada jumlah daun tanaman bawang merah. Hasil uji respons ketahanan tanaman bawang merah terhadap PGPR indigenous secara tunggal ditunjukkan pada Gambar 1. Hasil analisis ragam enzim peroksidase menghasilkan data yang tidak berbeda nyata. Pemberian PGPB indigenous tidak memberikan pengaruh yang berbeda terhadap aktivitas enzim peroksidase. Nilai aktivitas peroksidase yang tidak berbeda nyata diduga karena kemampuan yang dimiliki oleh semua PGPB indigenous hampir sama atau PGPB belum bisa memberikan induksi tanaman bawang merah dengan baik. Enzim peroksidase telah banyak dilaporkan memiliki peran penting pada ketahanan tanaman melawan infeksi patogen. Enzim peroksidase meningkatkan ketahanan tanaman dengan membentuk struktur penghalang pada sel tanaman untuk menghalangi masuknya patogen dengan cara melakukan katalis hidrosinamik dan polimerisasi gugus alkohol, hal tersebut dapat memperkuat dinding sel tanaman dan mengatur perkembangan dinding sel di dalam tanaman (Arrieta-Baez \& Stark, 2006). Pada beberapa penelitian PGPB memberikan nilai aktivitas peroksidase yang tinggi dibanding perlakuan kontrol. Aktivitas peroksidase lebih tinggi pada tanaman yang diberi perlakuan bakteri endofit dibandingkan kontrol (Resti et al., 2016). Selain itu pada penelitian Phabiola and Khalimi (2014), menyatakan bahwa perlakuan $P$. agglomerans formula gel dan powder dapat meningkatkan aktivitas peroksidase $46,84 \%$ hingga $52,49 \%$ pada 7 hari

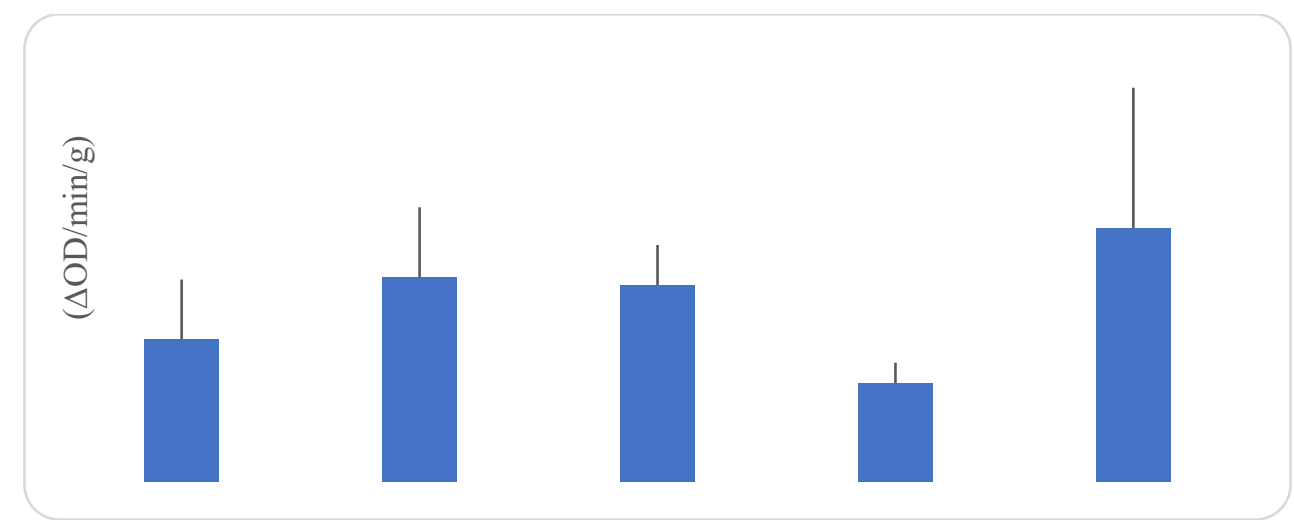

Gambar 1. Rerata enzim peroksidase dalam daun bawang merah pada 7 hari setelah tanam

Kelima isolat PGPB memberikan nilai pertumbuhan tanaman yang berbeda. Pseudomonas sp. pada penelitian ini memberikan nilai yang paling tinggi pada parameter tinggi tanaman bawang merah pada 20 hari setelah tanam namun tidak lebih baik dari keempat PGPB yaitu $B$. mycoides, Clostridium sp. Alcaligenes faecalis, dan Erwinia sp. PGPB indigenousB. mycoides dan Clostridium sp. adalah bakteri Gram positive yang memiliki endospore sebagai alat pertahanan di lingkungan yang buruk (Dinata et al, 2021). Bal et al., 2013 menyatakan bahwa Bacillus sp. dan Alcaligenes sp. menunjukkan aktivitas 
ACC deaminase sehingga dapat mentolerir garam sehingga mampu meningkatkan pertumbuhan tanaman padi di bawah kondisi cekaman. Beberapa penelitian mengenai Clostridium sp. dan Pseudomonas sp. juga telah banyak dilaporkan sebagai PGPB. Sebuah studi yang dilakukan Tsavkelova et al.,(2006), melaporkan bahwa Clostridium sp. mampu menghasilkan senyawa giberelin yang dapat meningkatkan pertumbuhan tanaman. Selain itu,Polyanskaya et al., (2002) juga melaporkan bahwa inokulasi Clostridium sp. pada mentimun dapat meningkatkan pertumbuhan secara signifikan.

Penelitian ini merupakan penelitian awal tanpa perlakuan inokulasi patogen sehingga enzim pertahanan belum mencapai nilai yang optimal. Hal tersebut didukung oleh Farahani \& Taghavi, (2016), peningkatan aktivitas enzim pertahanan seperti enzimkatalase dan peroksidase pada tanaman terjadi karena tanaman terinfeksi oleh patogen dan nonpatogen. Selain itu keberhasilan dan efisiensi PGPB sebagai inokulan pada tanaman pertanian dipengaruhi oleh berbagai faktor, antara lain kemampuan bakteri tersebut untuk menjajah akar tanaman, eksudasi oleh akar tanaman dan kesehatan tanah (de Souza et al., 2015). PGPB merespon tanaman eksudat melalui modulasi ekspresi beberapa gen, seperti yang terkait dengan eksopolisakarida (EPS) biosintesis dan pembentukan biofilm (Beauregard et al., 2013). Selain itu, kompetisi mikrobajuga memiliki pengaruh dengan efisiensi kolonisasi akar dengan PGPB, karena eksudasi senyawa yang berbeda dengan akar tanaman dapat menarik populasi mikroba lainnya (de Souza et al., 2015).

\section{KESIMPULAN}

Pemberian PGPB indigenous memberikan pengaruh terhadap tinggi tanamanbawang merah namun tidak memberikan pengaruh pada jumlah daun dan enzim peroksidase tanaman bawang merah.

\section{UCAPAN TERIMA KASIH}

Penulis menyampaikan terimakasih kepada Jurusan Hama dan Penyakit Tumbuhan Universitas Brawijaya karena memberikan izin untuk melakukan penelitian di Laboratorium Penyakit Tumbuhan di waktu pandemi.

\section{DAFTAR PUSTAKA}

Arrieta-Baez, D., \& Stark, R. E. (2006). Modeling Suberization With Peroxidase-Catalyzed Polymerization of Hydroxycinnamic Acids Cross Coupling and Dimerization Reactions. Phytochemistry, 67(7), 743-753. https://doi.org/10.1016/j.phytochem. 2006.01.026

Bal, H. B., Nayak, L., Das, S., \& Adhya, T. K. (n.d.). Isolation of ACC Deaminase Producing PGPR from Rice Rhizosphere and Evaluating Their Plant Growth Promoting Activity Under Salt Stress. Plant and Soil, 366, 93-105. https://doi.org/https://doi.org/10.1007 /s11104-012-1402-5

Beauregard, P. B., Chai, Y., Vlamakis, H., Losick, R., \& Kolter, R. (2013). Bacillus subtilis Biofilm Induction by Plant Polysaccharides. PNAS, 16211630.

https://doi.org/10.1073/pnas.1218984 110

de Souza, R., Ambrosini, A., \& Passaglia, L. M. P. (2015). Plant growthpromoting bacteria as inoculants in agricultural soils. Genetics and Molecular Biology, 38(4), 401-419. https://doi.org/10.1590/S1415475738420150053

Dinata, G. F. (2018). Potensi Bakteri Dari Serasah Tanaman Kopi Di Ub Forest Untuk Mengendalikan Penyakit 
Busuk Pangkal Batang (Fusarium oxysporum f.sp. cepae) pada Tanaman Bawang Merah (Brawijaya University). Retrieved from http://repository.ub.ac.id/161638/

Dinata, G. F., Aini, L. Q., \& Kusuma, R. R. (2021). Identification and Characterization of Antagonistic Bacteria from Coffee Plant Litter. Agrotechnology Research Journal, 5(1), 32-37. https://doi.org/10.20961/agrotechresj. v5i1.49716

Dinata, G. F., Ariani, N., Purnomo, A., \& Aini, L. Q. (2021). Pemanfaatan Biodiversitas Bakteri Serasah Kopi Sebagai Solusi Pengendali Penyakit Moler Pada Bawang Merah. Jurnal Hama Dan Penyakit Tumbuhan, 9(1), 28-34.

https://doi.org/10.21776/ub.jurnalhpt. 2021.009.1.5

Farahani, A. S., \& Taghavi, M. (2016). Changes of Antioxidant Enzymes of Mung Bean [Vigna radiata (L.) $\mathrm{R}$. Wilczek] in Response to Host and Non-host Bacterial Pathogen. Journal of Plant Protection Research, 56(1), 1-5. https://doi.org/10.1515/jppr2016-0016

Gamalero, E., \& Glick, B. R. (2011). Mechanisms Used by Plant GrowthPromoting Bacteria. In M. D. (Ed.), Bacteria in Agrobiology: Plant Nutrient Management. https://doi.org/https://doi.org/10.1007 /978-3-642-21061-7_2

Hafri, N. D., Sulistyaningsih, E., Wibowo, A., Hama, D., Pertanian, F., \& No, J. F. (2020). Pengaruh Aplikasi Plant Growth Promoting Rhizobacteria terhadap Pertumbuhan dan Hasil Tanaman Bawang Merah (Allium cepa L . Aggregatum group). Vegetalika, 9(4), 512-524.

Isniah, U. S., \& Widodo. (2015). Eksplorasi Fusarium Nonpatogen untuk Pengendalian Penyakit Busuk
Pangkal pada Bawang Merah. Jurnal Fitopatologi Indonesia, 11(1), 14. https://doi.org/10.14692/jfi.13.1.14

Khalimi, K., \& Wirya, G. N. A. S. (2009). Pemanfaatan Plant Growth Promoting Rhizobacteria untuk Biostimulants dan Bioprotectants. Ecotrophic, 4(2), 131-135.

Patading, G. F., \& Ai, N. S. (2021). Efektivitas Penyiraman PGPR (Plant Growth Promoting Rhizobacteria) terhadap Tinggi, Lebar Daun dan Jumlah Daun. Biofaal Journal, 2(1), 35-41.

Phabiola, T. A., \& Khalimi, K. (2014). Pengaruh Aplikasi Formula Pantoea agglomerans Terhadap Aktivitas Antioksidan dan Kandungan Klorofil Daun Tanaman Strowberi. Agrotrop: Journal on Agriculture Science, 2(2), 125-131.

Polyanskaya, L. M., Vedina, O. T., V., L. L., \& Zvyagintsev, D. G. (n.d.). The Growth-promoting Effect of Beijerinckia mobilis and Clostridium sp. Microbiology, 71, 109-115. https://doi.org/https://doi.org/10.1023 /A:1017914803544

Resti, Z., Habazar, T., \& Putra, D. P. (2016). Aktivitas Enzim Peroksidase Bawang Merah yang Diintroduksi dengan Bakteri Endofit dan Tahan terhadap Penyakit Hawar Daun Bakteri (Xanthomonas axonopodis pv. Allii). J. HPT Tropika, 16(2), 131137.

Tsavkelova, E. A., Klimova, S. Y., Cherdyntseva, T. A., \& Netrusov, A. I. (2006). Microbial producers of plant growth stimulators and their practical use: A review. Appl Biochem Microbiol, 42, 117-126. Retrieved from https://doi.org/10.1134/S0003683806 020013 